2019-02

Protein provision in critically ill adults requiring enteral nutrition: Are guidelines being met?

Collinson, Avril

http://hdl.handle.net/10026.1/12697

10.1002/ncp.10209

Nutrition in Clinical Practice

SAGE Publications

All content in PEARL is protected by copyright law. Author manuscripts are made available in accordance with publisher policies. Please cite only the published version using the details provided on the item record or document. In the absence of an open licence (e.g. Creative Commons), permissions for further reuse of content should be sought from the publisher or author. 


\section{Protein provision in critically ill adults requiring enteral nutrition: Are guidelines being met?}

\section{Abstract}

Background: In a previous audit, $81 \%$ of enteral protein prescriptions failed to meet protein guidelines. To address this, a very high protein enteral formula and protein supplements were introduced, and protein prescriptions were adjusted to account for non-nutritional energy sources displacing enteral formula. This follow-up audit compared protein provision in critically ill adults requiring exclusive enteral nutrition (EN), firstly, to local and international guidelines and, secondly, following changes to practice, with the previous audit in the same ICU.

Methods: Data collected from 106 adults consecutively admitted to the ICU of a UK tertiary hospital and requiring exclusive $\mathrm{EN} \geq 3$ days. Protein targets based on local guidelines (1.25, 1.5 or $2.0 \mathrm{~g} / \mathrm{kg} / \mathrm{day}$ ), nutrition prescription and delivery were recorded for 24 -hours between days $1-3,5-7,8-10$, and 18-20 post-ICU admission.

Results: On day 1-3, the proportion of protein prescriptions meeting protein targets increased from $19 \%$ in 2015 , to $69 \%$ in $2017(p<0.0005$, phi=0.50). Nutrition delivery met protein targets for only $22 \%$ of patients. For all patients, on average, prescriptions met $103 \%$ of the protein target, and $79 \%$ of the protein target was delivered $(p<0.0005, r=0.53)$. The proportion of protein prescriptions meeting protein targets was similar for days 1-3 (69\%), 57 (71\%), and 8-10 (68\%), but increased slightly by day $18-20(74 \%)$. The proportion of patients for which EN delivery met protein targets increased with number of days post-ICU admission $(22 \%, 26 \%, 37 \%$, and $53 \%$ for day $1-3,5-7,8-10$, and $18-20$, respectively). Conclusion: The proportion of protein prescriptions meeting guideline targets was higher following changes to practice.

Keywords: critical care; enteral nutrition; protein; overfeeding; nutritional requirements 


\section{Introduction}

Catabolism of lean body mass during critical illness is associated with impaired immunity and wound healing, and weakness (1-4). Catabolism mobilises energy substrates and amino acids to maintain the acute-phase protein response (5). Nutrition, particularly protein, is key in attempting to minimise catabolism and maintain the acute-phase protein response during critical illness (5). Observational prospective cohort studies show an association between increased protein provision ( $\geq 1.2 \mathrm{~g} / \mathrm{kg} /$ day) and improved clinical outcomes $(6-8)$, but exact dose and timing have not been defined (9).

Currently, for critically ill adults, the American Society for Parenteral and Enteral Nutrition (ASPEN) recommends $1.2-2.5 \mathrm{~g} / \mathrm{kg} /$ day of protein, and $2.0-2.5 \mathrm{~g} / \mathrm{kg}$ ideal body weight (IBW)/day if BMI is $>30 \mathrm{~kg} / \mathrm{m}^{2}(10)$; the European Society for Clinical Nutrition and Metabolism (ESPEN) recommends $1.3-1.5 \mathrm{~g} / \mathrm{kgIBW} /$ day (11). This compares to the Recommended Dietary Allowance (RDA) for protein intake in healthy adults of $0.8 \mathrm{~g} / \mathrm{kg} / \mathrm{day}$ (12).

It is difficult to achieve these goals without overfeeding energy (13) because the non-protein energy to nitrogen ratio (NPE:gN) of most enteral formulas and common use of nonnutritional energy (NNE) sources, such as Propofol and citrate regional anticoagulation, are too high (14).

Randomised controlled trials (RCTs) are required to define the effect of dose and timing of protein provision on clinical outcomes. However, we first need to establish how to provide high levels of protein without overfeeding energy.

There is a large deficit between protein guidelines versus prescription (14), and enteral/parenteral protein prescription versus delivery in intensive care units (ICU) worldwide (15-17). In a previous audit in the study ICU, only $19 \%$ of enteral protein prescriptions met local guidelines (14). It was shown that, in theory, use of protein supplements and 
adjustment of protein prescriptions for NNE could significantly increase the proportion of patients meeting protein guidelines (14).

As far as the authors are aware, no studies have compared both prescription and delivery of protein, to guidelines in critically ill adults. Following on from the audit of enteral protein prescriptions reported by Taylor et al. (14) at the same ICU, this follow-up audit determines whether protein targets, based on guidelines (see Methods, Table 1), are met by enteral nutrition (EN) prescriptions and delivery, since implementing improvements in prescribing practice and EN products.

For the purpose of this study, nutrition prescription is defined as the total nutrition prescribed from enteral formula, supplements and NNE sources per day. Nutrition delivery is the total nutrition actually provided to the patient from enteral formula, supplements and NNE sources per day.

Aims: 1) to compare protein provision in critically ill adults requiring exclusive EN (via feeding tube) to local and international guidelines; 2) to provide a comparison with the previous audit of protein prescriptions in the same ICU following changes to practice.

\section{Methods}

Changes to practice in EN provision

Previous practice at the study ICU was for EN to be prescribed to meet the protein goal when no NNE was delivered. This meant that until NNE (usually Propofol) stopped, EN was limited to prevent overfeeding, therefore protein goals were often not met. The highest protein enteral formula available on the ICU was Nutrison Protein Plus (Nutricia, Wiltshire, UK; $6.3 \mathrm{~g}$ protein, $14.2 \mathrm{~g}$ carbohydrate, $125 \mathrm{kcal}$ per $100 \mathrm{ml}$; NPE:gN 99:1). No protein supplements were stocked for use on the ICU. 
Following the findings of the previous audit (14), where possible, dietitians prescribed EN to meet the full protein target accounting for a reduced rate of enteral formula delivery due to the presence of Propofol. This was facilitated by using a protein supplement (ProSource ${ }^{\circledR}$ TF; Nutrinovo, Kent, UK; $11 \mathrm{~g}$ protein, $1 \mathrm{~g}$ carbohydrate, 44kcal per $45 \mathrm{ml}$ ) and/or a very high protein enteral formula (Fresubin ${ }^{\circledR}$ Intensive; Fresanius Kabi, Cheshire, UK; $10 \mathrm{~g}$ protein, $12.9 \mathrm{~g}$ carbohydrate, $122 \mathrm{kcal}$ per $100 \mathrm{ml}$; NPE:gN 51:1). Where the volume of enteral formula prescribed was less than the nutritionally complete volume, to provide basic micronutrient requirements, a soluble multivitamin was also prescribed.

\section{Participants}

Adults ( $\geq 18 \mathrm{y}$ ) admitted to the ICU of a tertiary hospital in the UK between $22^{\text {nd }}$ April 2017 and $12^{\text {th }}$ July 2017 were included prospectively if they required exclusive EN on ICU admission. Exclusion criteria were: exclusive EN no longer required or discontinued, or the patient discharged from ICU, within 72 hours of admission; patient not referred to the dietitian for EN within 72 hours of admission; clinical EN or protein restriction e.g. high refeeding risk, renal impairment requiring conservative management, liver dysfunction refractory to treatment, or GI dysfunction; PN indicated; oral nutrition commenced; or palliative care.

\section{Data collection}

Patient characteristics were recorded on admission. Weight and height were taken from the patient's notes and were usually estimated or based on relatives' report or previous General Practitioner's (GP) or hospital records.

Nutritional assessment and prescriptions were completed, and reviewed daily Monday to Friday, by experienced critical care dietitians. Resting metabolic rate (RMR), used to calculate estimated energy requirement (EER), was estimated using validated predictive equations for ventilated critically ill adults (18) and non-ventilated acutely ill adults (19), based on changing physiological parameters as well as body weight. For non-ventilated 
burns patients, the validated Toronto equation was used when deemed most appropriate by the dietitian (20).

Dietitians estimated individualised protein targets based on local guidelines. Local and international guidelines for protein provision in critically ill adults are shown in Table 1. For patients with $\mathrm{BMI}>25 \mathrm{~kg} / \mathrm{m}^{2}$, an IBW equivalent to a BMI of $25 \mathrm{~kg} / \mathrm{m}^{2}$ was used when calculating protein targets using local guidelines. Local guidelines span most of the range recommended in the ASPEN guidelines and therefore identifying whether protein prescriptions and delivery met protein targets based on local guidelines also shows whether ASPEN guidelines for protein provision can be met (10).

Nutritional data were collected for one day during each of the following time periods in a patient's ICU stay: days 1-3, 5-7, 8-10, and 18-20. Day 1-3 of ICU stay was the primary data collection period, as protein prescriptions aimed to match target from day 1 , and all patients included required exclusive EN for $\geq 3$ days. The first day audited for each patient was the first full day on the ICU after the patient had been assessed and target EN prescribed by a dietitian. The primary data collection period, day 1-3, matches that used in the 2015 audit, enabling direct comparison (14). Data collection was discontinued early if the patient no longer met the inclusion criteria.

Data was collated from patient dietetic records. Nutritional data collected were: energy and protein targets based on local guidelines; equation used to calculate EER; reason for hypocaloric feeding, if appropriate; predicted and delivered NNE (Propofol, IV glucose, citrate); nutrition prescription; enteral formula, supplements, and enteral fluid administered; gastric residual volumes (GRV) discarded or vomited. For patients on continuous renal replacement therapy (CRRT) receiving citrate as anticoagulant in the continuous venovenous haemofiltration $(\mathrm{CVVH})$ solution, it was assumed that they received an additional $200 \mathrm{kcal} / \mathrm{day}$, as it was not possible to determine individualised values (21). 
The protein prescription was calculated from the volume of enteral formula and supplements prescribed. Protein delivery was the amount of protein actually received by the patient in the enteral formula and supplements administered, minus gastric losses. In calculating nutrition delivery, gastric losses were accounted for, to identify how much exogenous protein was received into the small intestine and was therefore available for absorption.

Nutritional adequacy

Nutritional adequacy criteria were defined as $\geq 90 \%$ of the protein target and $\geq 130 \mathrm{~g} /$ day carbohydrate (obligatory glucose requirement) (12) without overfeeding energy ( $\leq 100 \%$ EER), as used in the 2015 audit (14). The protein supplement provides protein in increments of $11 \mathrm{~g}$ and therefore prescriptions could rarely achieve exactly $100 \%$ of protein target. The number of protein supplements prescribed was rounded down and therefore the value of $\geq 90 \%$ of protein target was chosen to match protein goals associated with improved clinical outcomes in mechanically ventilated, critically ill adults $(>90 \%$ of $1.2-1.5 \mathrm{~g} / \mathrm{kg} / \mathrm{day}$ or based on nitrogen balance) (8).. It was assumed this optimises protein utilisation, minimising reliance on gluconeogenesis of amino acids and glycerol (14). The final adequacy criteria required that energy from all sources was $\leq 100 \%$ of EER, to avoid consequences of overfeeding $(22,23)$; obese patients received hypocaloric prescription, well below $100 \%$ of EER but with adequate protein to minimise catabolism $(10,24)$. Results from analyses considering nutritional adequacy can be found in supplementary material (Table S1).

\section{Statistical analyses}

Variables were assessed for normal distribution using Q-Q plots and the Shapiro-Wilk test. Continuous variables that were normally distributed are described as mean $\pm S D$. Nonnormally distributed continuous variables are described as median with interquartile range (IQR). Categorical variables are described as a percentage.

Fisher's exact test was used to compare the proportion of protein prescriptions meeting protein targets based on local guidelines in the current audit to the 2015 audit (14), and phi 
calculated to identify effect size. Wilcoxon's signed rank test, with calculation of effect size r, was used to compare the difference between protein targets and protein prescriptions, and protein targets and protein delivery. Wilcoxon's signed rank test was also used to compare the difference in the percentage of protein target met by prescription versus the percentage of protein target met by delivery. Continuous variables were compared between the 2015 and 2017 samples using the Mann Whitney $U$ test, with calculation of effect size $r$. The Mann Whitney $\mathrm{U}$ test was also used to compare continuous variables in subgroup analysis. Categorical variables were compared between the same independent samples using Fisher's exact test with phi or Cramer's V reported as effect size, as appropriate. Subgroup analysis compared groups based on previously identified risk factors for failing to achieve protein targets (14). All statistical tests performed were two-tailed. Magnitude of effect sizes were determined based on Cohen's guidelines: $0.1=$ small, $0.3=$ medium, $0.5=\operatorname{large}(25)$.

Guidance from the National Audit Office suggests that a sample size of 100 is sufficient for most audit purposes (26). A sample of 106 patients was included in the primary analyses for day 1-3 post ICU admission. A retrospective sample size calculation showed that, for the proportion of the sample identified as achieving the standard (protein targets based on local guidelines) with protein prescription, and protein delivery, and with this sample size of 106 patients, accuracy was approximately $\pm 8 \%$ with a confidence level of $95 \%$ (27).

\section{Ethics}

This project was accepted and registered as an audit by the local NHS Trust and the University to which authors were affiliated. NHS ethics approval was not required as all audit data were routinely collected for clinical purposes.

\section{Results}

Sample characteristics 
One hundred and six ICU patients requiring exclusive EN were included (Table 2). The majority of patients had a protein target of $1.25 \mathrm{~g} / \mathrm{kg} /$ day based on local guidelines (Table 3 ). Baseline characteristics of patients included in the 2015 (14) and 2017 audits were similar (Table 2). The large proportion of trauma and neurosurgery patients reflects the hospital being a regional major trauma centre.

Protein prescription and delivery compared to guidelines

The proportion of protein prescriptions meeting protein targets based on local guidelines on day 1-3 of ICU admission increased from $19 \%(n=27 / 139)$ in 2015 to $69 \%(n=73 / 106)$ in 2017, with large effect size $(p<0.0005$, phi $=0.50)$.

A higher percentage of patients' protein target was prescribed in 2017 compared to 2015 (median 103\%, IQR 97-108, versus 75\%, IQR 62-95; $\mathrm{p}<0.0005, \mathrm{r}=0.54$ : large effect size). In the 2017 audit, 99\% (105/106) of protein prescriptions achieved over $75 \%$ of their protein target with prescription, the median proportion achieved in the 2015 audit. Protein targets in 2015 were slightly higher than in 2017 (median 108.3g/day, IQR 84.4-129.2, versus 97.2g/day, IQR, 84.0-116.4; $\mathrm{p}=0.135, \mathrm{r}=0.09$ : small effect size; normalized: median $1.32 \mathrm{~g} / \mathrm{kg} /$ day, IQR $1.10-1.88$, versus $1.25 \mathrm{~g} / \mathrm{kg} /$ day, IQR $1.17-1.50)$.

Figure 1 shows a comparison over time between the percentage of protein prescriptions meeting protein targets based on local guidelines and the percentage of patients meeting protein targets with EN delivery.

The median protein prescription on day 1-3 was $3 g$ higher than the protein target, but not of clinical significance. Protein delivery on day 1-3 was lower than protein target (median 79g versus $97 \mathrm{~g}, \mathrm{z}=-6.89, \mathrm{p}<0.0005, \mathrm{r}=0.47$ : medium-large effect size) with the difference of $18 \mathrm{~g}$ between median protein target and delivery being potentially clinically significant (Figure 2). Median percentage of protein target met by delivery on day $1-3$ was $79 \%$ versus $103 \%$ for the percentage of protein target met by prescription $(z=-7.70, p<0.0005, r=0.53$ : large effect size). 
Complete data for energy and protein targets, prescription and delivery can be found in Table S2.

Risk factors for inadequate EN

Patients with the highest protein target, $2.0 \mathrm{~g} / \mathrm{kg} / \mathrm{day}$, were less likely to meet their protein target with prescription (46\% versus $79 \%$ and $75 \%$ for targets of $2.0,1.5$ and $1.25 \mathrm{~g} / \mathrm{kg} / \mathrm{day}$ respectively, $p=0.027$, Cramer's $V=0.27$ : medium effect size). For delivery, there was a trend in the same direction ( $12 \%$ versus $21 \%$ and $25 \%$ for targets of $2.0,1.5$ and $1.25 \mathrm{~g} / \mathrm{kg} /$ day respectively, $p=0.489$, Cramer's $V=0.13$ : small effect size).

Patients prescribed hypocaloric nutrition due to obesity or metabolic intolerance were more likely to meet their protein target with prescription ( $84 \%$ versus $66 \%, p=0.171$, phi $=0.155$ : small effect size). The same analysis could not be done for delivery due to insufficient numbers in some groups.

For delivery, NNE as a percentage of total energy was higher in the group that failed to meet their protein target compared to those who met their protein targets (median 10\%, IQR 0-23, versus $6 \%$, IQR 0-9, $U=680, z=-1.922, p=0.055, r=0.19$ : small effect size).

\section{Discussion}

Changes in prescribing practices, made in response to the 2015 audit (14), were associated with more protein prescriptions meeting protein targets based on local guidelines, increasing from 19\% (2015) to $69 \%$ (2017); the slightly lower protein targets in 2017 are unlikely to have contributed significantly.

The proportion of protein prescriptions meeting targets was similar over the first 10 days of ICU admission (68-71\%) with a small increase by day $18-20$ (74\%). It is likely that this was partly due to a reduced proportion of patients with higher protein targets ( 1.5 or $2.0 \mathrm{~g} / \mathrm{kg} / \mathrm{day})$ 
at day 18-20 and a reduction in NNE permitting easier attainment of protein targets without overfeeding.

There was a trend for protein targets not to be met by prescriptions in patients with the highest protein targets $(2.0 \mathrm{~g} / \mathrm{kg} /$ day $)$. At the time of this follow-up audit, dietitians tended to round down the number of protein supplements prescribed making it more likely that patients would be slightly under-prescribed rather than over-prescribed protein. Due to the common under-delivery of EN, it may be beneficial to encourage dietitians to round up the number of supplements. Patients with high BMI, and therefore requiring hypocaloric feeding, were at increased risk of not meeting protein targets and the obligatory glucose requirement in the 2015 audit (12) but not in the follow-up audit..

As seen in previous studies, there was a large gap between protein prescription and delivery $(15,16)$. Only $22 \%$ of patients actually received their protein target on day $1-3$, but this increased to $53 \%$ by day $18-20$. Median percent of protein target met by EN delivery, on day 1-3 of ICU admission, was 79\% (IQR, 54-99) compared to 103\% (IQR, 97-109) with prescription. Whereas the prescription IQR was narrow and straddled $100 \%$, the IQR for delivery was wide and below $100 \%$ showing that non-prescription factors impair the meeting of targets. These factors were not investigated in the current study but have been reported elsewhere to commonly include delays for tests and procedures, Gl intolerance, and feeding tube problems (28). Improvement in EN delivery with number of days post ICU admission has also previously been described (7), and is likely due to improvements in Gl tolerance, and reduced delays for procedures (28).

Further research is needed to investigate ways to improve EN delivery. Specifically, issues with enteral access and GI intolerance that limit EN delivery need to be investigated. We need to identify safe and effective solutions to reduce the frequency and severity of these problems or to provide alternative methods for delivering EN that bypass these issues. 
Where EN prescriptions still fail to meet requirements in some cases, specific clinical reasons such as biochemical abnormalities and organ dysfunction need to be investigated.

High NNE provision was the main risk factor for failing to meet protein target with EN delivery on day 1-3. Protein prescriptions were adjusted for predicted NNE, but when NNE delivery was higher than predicted, enteral formula and therefore protein delivery would be reduced, preventing protein target being met. Raising awareness of the impact of NNE sources on patients' nutrition amongst the ICU multi-disciplinary team is important to facilitate changes that may be implemented to reduce the amount of NNE, for example changing type and/or dose of sedatives and IV fluids/solutions.

Local protein guidelines $(1.25,1.5$, or $2.0 \mathrm{~g} / \mathrm{kg} /$ day based on CRP level) span most of the range recommended by ASPEN (1.2-2.5g/kg/day), therefore the factors suggested to affect protein prescription and delivery should largely apply to protein targets based on ASPEN guidelines (10). Lack of objective criteria for choosing an individual's protein target risk arbitrary choice between $1.2-2.5 \mathrm{~g} / \mathrm{kg} /$ day; to avoid this, local guidelines match target to CRP level based on the consensus that higher input is of benefit in more severe illness. The current and previous audit carried out on the same ICU (14) are the only studies that have directly compared protein prescription to guideline targets. The most recent published data from the International Nutrition Survey (INS) report protein adequacy (percent of prescription met by delivery) for artificial nutrition (EN and PN) of $57.6 \%$ for all countries, and $69.8 \%$ for Europe and South Africa (16). In the current audit, median percentage of protein target achieved with EN delivery was $79 \%$ and $102 \%$ on days $1-3$ and $18-20$, respectively. The relative improvement of the current audit over INS results may be even larger because of differences in the way that data were collected and analysed. Although most INS patients were prescribed EN, delivery for those on PN was likely to be closer to prescription $(15,16)$. Mean protein prescription $( \pm S D$ ) was $1.2 \mathrm{~g} / \mathrm{kg} /$ day \pm 0.3 in the INS (16) compared to higher and harder to attain protein targets of $1.25-2.0 \mathrm{~g} / \mathrm{kg} /$ day in this audit. In this audit, EN delivery 
was adjusted for gastric losses, providing a more valid measure of the nutrition available to the patient for absorption. In contrast, exclusion of patients commencing partial oral intake from the current audit may have contributed to higher reported delivery in comparison to the INS.

A retrospective USA audit recorded protein adequacy from EN at day 3 of ICU admission, providing a similar comparison to day 1-3 delivery in the current audit (17). Protein adequacy was only $17 \%$ for the American sample of mostly medical ICU patients (17). The current audit was at a major trauma centre and therefore included a large proportion of trauma and neurosurgery patients. In the American audit, only $9 \%$ of patients audited received $80 \%$ or above of their protein prescription on day 3 , compared to $22 \%$ of patients in the current audit who received $100 \%$ of their protein target based on local guidelines, on day 1-3 of ICU admission (17).

Prospective cohort studies carried out in the Netherlands report a higher proportion of patients achieving their protein target with EN delivery $(6,29)$. Weijs et al. (6) report that $30 \%$ of patients achieved at least $1.2 \mathrm{~g} / \mathrm{kg} /$ day during the period of mechanical ventilation when targets were set at $1.2-1.5 \mathrm{~g} / \mathrm{kg} /$ day. This is higher than the current audit on day $1-3$ (22\%), but by day $18-2053 \%$ met their protein target and these targets were higher (1.25$2.0 \mathrm{~g} / \mathrm{kg} /$ day) and therefore more difficult to achieve.

The findings of the current audit, and other literature in this area, indicate that it is important for ICUs to audit their EN prescriptions and delivery to identify potential deficits. Based on this follow-up audit, it is suggested that protein deficits may be reduced significantly by the availability of a very high protein enteral formula and an enteral protein supplement. Consideration of the displacement of EN by NNE sources such as Propofol is important, particularly early in a patient's ICU stay, and protein prescriptions should be adjusted accordingly. 
Prescribing adequate protein without overfeeding energy or restricting other nutrients such as carbohydrate, electrolytes and micronutrients is a difficult balancing act. The ability to prescribe (and potentially therefore deliver) a balance of EN that is optimal for the critically ill patient is more likely to be achieved when the prescriber has access to both a range of enteral formulas that includes one with a low NPE:gN ratio, and protein supplements easily administered via an enteral feeding tube. Further education of dietitians, physicians, and nurses is required to increase awareness of the potential for large nutritional deficiencies in ICU patients and changes they can make towards optimal prescribing and delivery of EN.

A limitation in this audit was the use of estimated or reported admission weight where no recent actual weight had been recorded. This represents a source of error in calculations of $\mathrm{BMI}, \mathrm{EER}$, and protein targets. However, use of estimated or reported weights reflects real world circumstances where accurate current weights are rarely available for critically ill patients.

In calculating EN delivery, the assumption that all GRV loss was enteral formula or fluid will underestimate input because of unmeasurable dilution by saliva or gastric juice. Additionally, when using a nasointestinal tube, it was assumed that if EN appeared in the GRV it meant all nasointestinal EN was really gastric; this may overestimate loss. Currently there is no clinical method of more accurately accounting for GRV loss, but to ignore it would overestimate the percentage of target met.

Another limitation is the small sample size available for the days 8-10 and 18-20 analysis due to the large number of patients meeting exclusion criteria by this point in their ICU stay. Larger patient numbers and testing of this protocol in other centres are required to determine whether the results are generalizable.

In conclusion, a larger proportion of ICU EN prescriptions and delivery met their protein targets using protein supplements and a low NPE:gN ratio enteral formula (51:1) with protein prescriptions adjusted to the current NNE input, versus previous practice of adjusting protein 
prescriptions to zero NNE and using NPE:gN ratio enteral formulas $\geq 99: 1$. It is therefore recommended that where patients require low NPE:gN ratios, enteral formula with a similar NPE:gN ratio and/or protein supplements should be stocked.

\section{Supplementary Material}

Tables S1 and S2 are available online at http://ncp.sagepub.com.

\section{References}

1. Batt J, dos Santos CC, Cameron JI, Herridge MS. Intensive care unit-acquired weakness: clinical phenotypes and molecular mechanisms. Am J Respir Crit Care Med. 2013;187(3):238-46 .

2. Puthucheary ZA, Rawal J, McPhail M, Connolly B, Ratnayake G, Chan P, et al. Acute skeletal muscle wasting in critical illness. J Am Med Assoc. 2013;310(15):1591-600.

3. Watters JM, Bessey PQ, Dinarello CA, Wolff SM, Wilmore DW. Both inflammatory and endocrine mediators stimulate host responses to sepsis. Arch Surg. 1986;121(2):17990.

4. Meyer NA, Muller MJ, Herndon DN. Nutrient support of the healing wound. New Horiz. 1994;2(2):202-14.

5. Hoffer LJ, Bistrian BR. Nutrition in critical illness: a current conundrum [version 1; referees: 2 approved]. F1000Research. 2016;5(F1000 Faculty Rev):2531.

6. Weijs PJM, Stapel SN, de Groot SDW, Driessen RH, de Jong E, Girbes ARJ, et al. Optimal protein and energy nutrition decreases mortality in mechanically ventilated, critically ill patients: a prospective observational cohort study. J Parentr Enter Nutr. 2012;36(1):60-8. 
7. Nicolo M, Heyland DK, Chittams J, Sammarco T, Compher C. Clinical outcomes related to protein delivery in a critically ill population. J Parentr Enter Nutr. 2015;40(1):45-51. 8. Song JH, Lee HS, Kim SY, Kim EY, Jung JY, Kang YA, et al. The influence of protein provision in the early phase of intensive care on clinical outcomes for critically ill patients on mechanical ventilation. Asia Pac J Clin Nutr. 2017;26(2):234-40.

9. Liebau F, Norberg $\AA$, Rooyackers O. Does feeding induce maximal stimulation of protein balance? Curr Opin Clin Nutr Metab Care. 2016;19(2):120-4.

10. McClave SA, Taylor BE, Martindale RG, Warren MM, Johnson DR, Braunschweig C, et al. Guidelines for the provision and assessment of nutrition support therapy in the adult critically ill patient: Society of Critical Care Medicine (SCCM) and American Society for Parenteral and Enteral Nutrition (A.S.P.E.N.). J Parentr Enter Nutr. 2016;40(2):159-211. 11. Singer P, Berger MM, Van den Berghe G, Biolo G, Calder P, Forbes A, et al. ESPEN guidelines on parenteral nutrition: Intensive care. Clin Nutr. 2009;28(4):387-400.

12. Institute of Medicine. Dietary reference intakes for energy, carbohydrate, fiber, fat, fatty acids, cholesterol, protein, and amino acids. Washington DC: National Academy Press; 2005

13. Jeejeebhoy KN. Permissive underfeeding of the critically ill patient. Nutr Clin Pract. 2004;19(5):477-80.

14. Taylor S, Dumont N, Clemente R, Allan K, Downer C, Mitchell A. Critical care: Meeting protein requirements without overfeeding energy. Clin Nutr ESPEN. 2016;11:e55e62.

15. Cahill NE, Dhaliwal R, Day AG, Jiang X, Heyland DK. Nutrition therapy in the critical care setting: What is "best achievable" practice? An international multicenter observational study. Crit Care Med. 2010;38(2):395-401.

16. Heyland DK, Dhaliwal R, Wang M, Day AG. The prevalence of iatrogenic underfeeding in the nutritionally 'at-risk' critically ill patient: Results of an international, multicenter, prospective study. Clin Nutr. 2015;34(4):659-66. 
17. Stewart ML, Biddle M, Thomas T. Evaluation of current feeding practices in the critically ill: A retrospective chart review. Intensive Crit Care Nurs. 2017;38:24-30.

18. Frankenfield DC, Coleman A, Alam S, Cooney RN. Analysis of estimation methods for resting metabolic rate in critically ill adults. J Parentr Enter Nutr. 2009;33(1):27-36.

19. Frankenfield DC, Ashcraft CM. Toward the development of predictive equations for resting metabolic rate in acutely ill spontaneously breathing patients. J Parentr Enter Nutr. 2016:0148607116657647.

20. Allard JP, Pichard C, Hoshino E, Stechison S, Fareholm L, Peters WJ, et al. Validation of a new formula for calculating the energy requirements of burn patients. $J$ Parentr Enter Nutr. 1990;14(2):115-8.

21. Oudemans-van Straaten HM, Ostermann M. Bench-to-bedside review: Citrate for continuous renal replacement therapy, from science to practice. Crit Care. 2012;16(6):249. 22. Weijs PJM, Looijaard WGPM, Beishuizen A, Girbes ARJ, Oudemans-van Straaten HM. Early high protein intake is associated with low mortality and energy overfeeding with high mortality in non-septic mechanically ventilated critically ill patients. Crit Care. 2014;18(6):701 .

23. Preiser JC, van Zanten ARH, Berger MM, Biolo G, Casaer MP, Doig GS, et al. Metabolic and nutritional support of critically ill patients: consensus and controversies. Crit Care. 2015;19(1):35.

24. Dickerson RN, Patel JJ, McClain CJ. Protein and calorie requirements associated with the presence of obesity. Nutr Clin Pract. 2017;32(1_suppl):86S-93S.

25. Cohen J. Statistical power analysis for the behavioural sciences. 2nd ed. Hillsdale, New Jersey: Erlbaum; 1988.

26. National Audit Office. A Practical Guide to Sampling: National Audit Office; 2006 [26/08/2017]. Available from: https://www.nao.org.uk/wp-

\section{content/uploads/2001/06/SamplingGuide.pdf.}

27. Fereday S. An introduction to statistics for local clinical audit and improvement. London: Healthcare Quality Improvement Partnership; 2015. 
28. Kim H, Stotts NA, Froelicher ES, Engler MM, Porter C. Why patients in critical care do not receive adequate enteral nutrition? A review of the literature. J Crit Care. $2012 ; 27(6): 702-13$

29. Strack van Schijndel RJM, Weijs PJM, Koopmans RH, Sauerwein HP, Beishuizen A, Girbes ARJ. Optimal nutrition during the period of mechanical ventilation decreases mortality in critically ill, long-term acute female patients: a prospective observational cohort study. Crit Care. 2009;13(4):1-11. 
Table 1. Local and international guidelines for protein provision in critically ill adults

\begin{tabular}{lll}
\hline Guideline & & Protein g/kg/day \\
\hline Local trust guidelines & CRP $<100$ & $1.25^{*}$ \\
& CRP $=100-149$ & $1.5^{*}$ \\
& CRP $\geq 150$ & $2.0^{*}$ \\
\hline ESPEN guidelines (Singer et al., 2009) & & $1.3-1.5^{\#}$ \\
\hline ASPEN guidelines (McClave et al., 2016) & Obese: BMl $>30 \mathrm{~kg} / \mathrm{m}^{2}$ & $1.2-2.5$ \\
& $\mathrm{BMl}>40 \mathrm{~kg} / \mathrm{m}^{2}$ & $2.0^{\#}$ \\
\hline
\end{tabular}

use IBW if BMI>25kg/m², ${ }^{\#}$ use IBW. CRP, C-reactive protein; IBW, ideal body weight; BMI, body mass index; ESPEN,

European Society for Parenteral and Enteral Nutrition; ASPEN, American Society for Parenteral and Enteral Nutrition.

Table 2. Comparison of baseline characteristics between 2015 and 2017

\begin{tabular}{|c|c|c|c|c|c|}
\hline \multirow{2}{*}{ Age, years* } & \multicolumn{2}{|c|}{$\begin{array}{l}2015 \\
\text { Taylor et al., } 2016 \text { (1 } \\
\quad \mathrm{n}=139\end{array}$} & \multicolumn{2}{|c|}{2017} & \multirow[b]{2}{*}{$\mathrm{p}=0.532$} \\
\hline & 59 & \pm 18 & 58 & \pm 17 & \\
\hline Sex male, n (\%) & 84 & $(60)$ & 54 & (51) & $p=0.154$ \\
\hline Weight, kg & 75.4 & $(65.0-88.0)$ & 75.5 & $(64.9-89.6)$ & $\mathrm{p}=0.841$ \\
\hline BMI, $\mathbf{k g} / \mathrm{m}^{2} \#$ & 24.9 & $(22.6-28.7)$ & 25.4 & $(22.5-28.7)$ & $\mathrm{p}=0.768$ \\
\hline APACHE II score ${ }^{\#}$ & 17 & $(13-23)$ & 16 & $(11-22)$ & $p=0.359$ \\
\hline Diagnosis category, n (\%) & & & & & $p=0.406$ \\
\hline Trauma & 41 & (29) & 38 & (36) & \\
\hline Neurosurgery (non-trauma) & 29 & (21) & 27 & (26) & \\
\hline Surgery (other) & 15 & (11) & 9 & (9) & \\
\hline Medical & 54 & (39) & 32 & (30) & \\
\hline
\end{tabular}

"mean \pm SD, "median (IQR). BMI, body mass index; APACHE II score, Acute Physiology and Chronic Health Evaluation II score; n, number of participants; SD, standard deviation; IQR, interquartile range. 
Table 3. 2017 protein targets based on local guidelines

\begin{tabular}{|c|c|c|c|c|}
\hline Days post-ICU & & Protein target, $r$ & & Patients, $n$ (\%) \\
\hline admission & $1.25 \mathrm{~g} / \mathrm{kgBW}^{*} / \mathrm{day}$ & $1.5 \mathrm{~g} / \mathrm{kgBW} / \mathrm{day}$ & $2.0 \mathrm{~g} / \mathrm{kgBW} / \mathrm{day}$ & \\
\hline $1-3$ & $63(59)$ & $19(18)$ & $24(23)$ & $106(100)$ \\
\hline $5-7$ & $28(43)$ & $14(22)$ & $23(35)$ & $65(61)$ \\
\hline $8-10$ & $22(58)$ & $6(16)$ & $10(26)$ & $38(36)$ \\
\hline $18-20$ & $16(84)$ & $1(5)$ & $2(11)$ & $19(18)$ \\
\hline
\end{tabular}

ideal body weight used if BMl>25kg/m². ICU, intensive care unit; BW, body weight; $n$, number of participants; BMl, body mass index.

Figure 1. Percentage of patients achieving protein targets with nutrition prescription and delivery

Figure 2. Protein targets based on local and international guidelines compared to prescription and delivery

Target=calculated daily requirement based on guidelines; Prescription=prescribed nutrition from enteral feed, supplements, and NNE; Delivery=actual nutrition received from enteral feed, supplements, and NNE. IQR, interquartile range; d, day post-ICU admission; BMI, body mass index $\left(\mathrm{kg} / \mathrm{m}^{2}\right)$; IBW, ideal body weight; ASPEN, American Society for Parenteral and Enteral Nutrition; ESPEN, European Society for Parenteral and Enteral Nutrition. 
Table S1. Table of frequency of nutrition prescriptions and delivery meeting nutritional adequacy criteria

Days post-ICU admission Number of prescriptions meeting

Number for which nutritional

adequacy criteria (\%)

delivery meets adequacy criteria (\%)

\begin{tabular}{r|cc}
\hline $\mathbf{1 - 3}(n=106)$ & $60(57)$ & $23(22)$ \\
$5-7(n=65)$ & $37(57)$ & $19(29)$ \\
$8-10(n=38)$ & $28(74)$ & $21(55)$ \\
$18-20(n=19)$ & $15(79)$ & $13(68)$
\end{tabular}

Adequacy criteria: $\geq 90 \%$ protein target; $\geq 130 \mathrm{~g} /$ day carbohydrate; $\leq 100 \% \mathrm{EER}$. ICU, intensive care unit; EER, estimated energy requirement; n, number of participants. 
Table S2. Table of nutrition outcomes

\begin{tabular}{|c|c|c|c|c|c|c|c|c|}
\hline \multicolumn{3}{|c|}{ Day 1-3 } & \multicolumn{2}{|c|}{ Day 5-7 } & \multicolumn{2}{|c|}{ Day 8-10 } & \multicolumn{2}{|c|}{ Day 18-20 } \\
\hline largets & & & & & & & & \\
\hline$E E R, \mathrm{kcal}^{+}$ & 1853 & $(1563-2147)$ & 2014 & (1658-2278) & 2028 & (1772-2283) & 2124 & $(1887-2321)$ \\
\hline Protein target $t^{\#}, g^{*}$ & 97.2 & $(84.0-116.4)$ & 102.4 & $(87.4-128.0)$ & 96.0 & $(80.9-128.1)$ & 95.7 & $(81.3-105.8)$ \\
\hline \multicolumn{9}{|l|}{ Prescription $^{b}$} \\
\hline Protein, $g^{*}$ & 100.0 & $(86.6-120.0)$ & 107.1 & $(92.1-130.0)$ & 100.8 & $(88.2-127.5)$ & 100.8 & $(94.5-113.4)$ \\
\hline Protein, $\%$ of target ${ }^{*}$ & 103 & $(97-108)$ & 102 & $(96-110)$ & 103 & $(99-113)$ & 107 & $(99-119)$ \\
\hline Total energy, $\mathrm{kcal}^{*}$ & 1757 & $(1586-2000)$ & 1952 & $(1616-2103)$ & 1952 & $(1740-2088)$ & 1977 & $(1750-2250)$ \\
\hline $\begin{array}{r}\text { Total energy, } \% \text { of } \\
E E R^{*}\end{array}$ & 99 & $(95-101)$ & 99 & $(94-102)$ & 99 & $(97-101)$ & 97 & $(90-99)$ \\
\hline Energy from EN, kcal & 1625 & $(1427-1671)$ & 1830 & $(1586-2037)$ & 1875 & (1669-2052) & 1875 & $(1713-2250)$ \\
\hline $\begin{array}{r}\% \text { of total energy from } \\
\qquad N^{*}\end{array}$ & 100 & $(85-100)$ & 100 & $(90-100)$ & 100 & $(100-100)$ & 100 & $(100-100)$ \\
\hline $\begin{array}{r}\text { Energy from NNE, } \\
k \mathrm{kcal}{ }^{*}\end{array}$ & 0 & $(0-264)$ & 0 & $(0-158)$ & 0 & $(0-0)$ & 0 & $(0-0)$ \\
\hline $\begin{array}{r}\% \text { of total energy from } \\
\qquad N E^{*}\end{array}$ & 0 & $(0-15)$ & 0 & $(0-10)$ & 0 & $(0-0)$ & 0 & $(0-0)$ \\
\hline \multicolumn{9}{|l|}{ Deliveryc } \\
\hline Protein, $g^{*}$ & 79.4 & $(50.4-99.6)$ & 89.8 & $(75.8-109.0)$ & 88.4 & $(74.5-119.1)$ & 94.7 & $(82.3-102.4)$ \\
\hline Protein, $\%$ of target ${ }^{*}$ & 79 & (54-99) & 90 & $(74-105)$ & 96 & $(83-107)$ & 102 & $(95-112)$ \\
\hline Total energy, $\mathrm{kcal}^{*}$ & 1299 & $(1051-1722)$ & 1636 & $(1199-1866)$ & 1731 & $(1488-1934)$ & 1842 & (1568-2026) \\
\hline $\begin{array}{r}\text { Total energy, \% of } \\
E E R^{*}\end{array}$ & 74 & $(52-93)$ & 85 & $(65-98)$ & 89 & (76-95) & 92 & $(71-97)$ \\
\hline Energy from EN, kcal & 1225 & $(857-1671)$ & 1569 & $(1177-1795)$ & 1688 & $(1369-1864)$ & 1813 & $(1531-2026)$ \\
\hline $\begin{array}{r}\% \text { of total energy from } \\
\qquad N^{*}\end{array}$ & 92 & $(80-100)$ & 98 & $(89-100)$ & 100 & $(97-100)$ & 100 & $(100-100)$ \\
\hline $\begin{array}{r}\text { Energy from NNE, } \\
k \mathrm{kcal}\end{array}$ & 98 & $(0-229)$ & 34 & $(0-186)$ & 0 & $(0-52)$ & 0 & $(0-13)$ \\
\hline $\begin{array}{r}\% \text { of total energy from } \\
N N E^{*}\end{array}$ & 8 & $(0-20)$ & 2 & $(0-11)$ & 0 & $(0-3)$ & 0 & $(0-0)$ \\
\hline
\end{tabular}

